Arq. Bras. Med. Vet. Zootec., v.66, n.3, p.641-647, 2014

\title{
Bacterial microbiota present in the gallbladder of cattle and antimicrobial resistance of Staphylococcus isolates
}

\author{
[Microbiota bacteriana presente na vesícula biliar de bovinos e resistência \\ antimicrobiana de isolados de Staphyloccocus] \\ F.S. Dias $^{1}$, I.F. Santos ${ }^{2}$, R.M. Franco ${ }^{2}$, E.R. Nascimento ${ }^{2}$ \\ ${ }^{1}$ Universidade Federal do Vale do São Francisco - UNIVASF - Petrolina, PE \\ ${ }^{2}$ Universidade Federal Fluminense - Faculdade de Veterinária - Niterói, RJ
}

\begin{abstract}
Pathogenic microorganisms can reside transiently or permanently in the gallbladder of cattle. Thus, during slaughter, more attention should be given to the gastrointestinal tract, especially to the accessory organ, the gallbladder. The main aim of this study was to characterize the bacterial microbiota present in bile and gallbladder epithelium of cattle slaughtered in a slaughtering plant under sanitary conditions and to evaluate the antimicrobial resistance in strains of the genus Staphylococcus. Thirty intact gallbladders were collected and the in bile and epithelium were researched for the presence of Aerobic Mesophilic Heterotrophic Bacteria (AMHB), Staphylococcus spp., total Enterobacteriaceae, Enterococcus spp. and Salmonella spp. The frequency of isolation of the microorganism mentioned above were, respectively: $23.02 \%, 14.39 \%, 13.67 \%, 24.46 \%, 0 \%$ and $24.46 \%$. Concerning both gallbladder environments, the frequency of isolation of the microorganisms in the epithelium was $64.03 \%$, and in the bile $35.97 \%$, with no statistical difference, but with significant difference between the population averages. In antimicrobial susceptibility testing, strains of Staphylococcus from both bile and gallbladder epithelium showed sensitivity to the antimicrobials: penicillin G, ceftriaxone, chloramphenicol and gentamicin. The observation that the gallbladder supports a high frequency of microorganisms brings us to the possible fact that cattle might be a persistent carrier of pathogens of great importance to public health.
\end{abstract}

Keywords: cattle gallbladder, pathogenic microorganisms, persistent carrier, public health

\section{RESUMO}

Microrganismos patogênicos podem residir temporariamente ou permanentemente na vesícula biliar de bovinos. Assim, durante o abate, maior atenção deve ser dada ao trato gastrointestinal, especialmente para o órgão acessório, a vesícula biliar. O principal objetivo deste estudo foi caracterizar a microbiota bacteriana presente na bile e no epitélio de vesículas biliares de bovinos abatidos em matadouro frigorífico sob inspeção sanitária e avaliar a resistência antimicrobiana de estirpes do gênero Staphyloccocus. Foram coletadas 30 vesículas biliares íntegras e foi pesquisada na bile e no epitélio do órgão a presença de bactérias heterotróficas aeróbias mesófilas (BHAM), Staphylococcus spp. e Enterobacteriaceae totais, Escherichia coli, Enterococcus spp. e Salmonella spp. A frequência de isolamento dos microrganismos citados acima foi, respectivamente: 23,02\%, 14,39\%, 13,67\%, 24,46\%, $0 \%$ e 24,46\%. Em relação aos dois ambientes da vesícula, a frequência de isolamento dos microrganismos no epitélio foi de 64,03\%, e na bile 35,97\%, não sendo diferente estatisticamente, mas com diferença significativa entre as médias populacionais. No teste de susceptibilidade aos antimicrobianos, as estirpes de Staphylococcus isoladas a partir da bile e do epitélio da vesícula biliar apresentaram sensibilidade a: penicilina $G$, ceftriaxona, cloranfenicol e gentamicina. A observação de que a vesícula biliar comporta microrganismos em elevadas frequências atenta para o fato de que o bovino possa ser um portador persistente de patógenos de grande importância em saúde pública.

Palavras-chave: vesícula biliar de bovino, microrganismos patogênicos, portador persistente, saúde pública

Recebido em 7 de março de 2012

Aceito em 12 de dezembro de 2013

E-mail: francesca.nobre@univasf.edu.br 


\section{INTRODUCTION}

Bile is a digestive secretion that plays a major role in the dispersion and absorption of fats. The composition of bile is complex, but can be thought of as lipid rich and protein poor (Gunn, 2000). Although the bile acids possess potent antimicrobial activity, recent research has shown that the bacterium is capable of tolerating high levels of bile and biofilm formation by pathogenic genera (Begley et al., 2009; Steenackers et al., 2011). The gallbladder may be a site of persistence and a source for fecal shedding of certain enteric food-borne pathogens resistant to many antimicrobial agents. Salmonella may form permanent colonies and biofilms in gallbladders, triggering the establishment of chronic, asymptomatic carriers (Steenackers et al., 2011). Bacteria in biofilms are generally well protected against environmental stresses, antibiotics, disinfectants and the host immune system (Jensen et al., 2010) and as a consequence, they are extremely difficult to eradicate. Previous studies (Mcdonough et al., 2000; Stoffregen et al., 2004; Reinstein et al., 2006; Jeong et al., 2007) reported isolation of E. coli O157:H7 and Salmonella in gallbladders of cattle and suggested that the organism can reside in these animals' organs. Thus, during slaughter, greater attention must be given to the gastrointestinal tract of cattle, especially the gallbladder, implicated as a site, source and reservoir for Salmonella spp and Escherichia coli $0157: \mathrm{H} 7$ among other pathogens. The main objective of this study was to characterize the bacterial microbiota present in bile and gallbladder epithelium of cattle slaughtered in a slaughtering plant under sanitary conditions and to evaluate the antimicrobial resistance in strains of the genus Staphylococcus.

\section{MATERIAL AND METHODS}

Intact gallbladders were collected from 30 randomly selected healthy cattle, judged after ante-mortem and post-mortem inspection, in a slaughtering plant under sanitary conditions in the southern state of Rio de Janeiro, Brazil. Immediately after collection the material was transported to the laboratory under refrigeration. Microbiological analysis was performed on the same day.
The gallbladder was opened in aseptic conditions, bile was collected and the biliary epithelium was sectioned with the aid of sterilized instruments. Bile and gallbladder epithelium were analyzed separately for Aerobic Mesophilic Heterotrophic Bacteria (AMHB), total Enterobacteriaceae, Staphylococcus aureus, Escherichia coli, Enterococcus spp. and Salmonella spp.

The AMHB and total Enterobacteriaceae count were performed as described by Brasil (2003) and colony isolation was carried out in Plate Count Agar (PCA, Merck) and Red Bile Glucose (VRBG) Agar (Merck), respectively. Plates were incubated at $37^{\circ} \mathrm{C}$ for 48 hours. Characteristic strains of Enterobacteriaceae family were tested for differential staining of Gram, oxidase, nitrate reduction and oxidation and fermentation $(\mathrm{O} / \mathrm{F})$ of glucose. For the genus Staphylococcus aureus, the analytical procedures of isolation followed the technique described by Brasil (2003). Aliquots of $0.1 \mathrm{~mL}$ of different dilutions were streaked, in duplicates, on the Baird-Parker agar surface. The plates were incubated inverted at 37 ${ }^{\circ} \mathrm{C}$ for 24 - 48 h. Typical colonies were selected. To characterize the genus the following tests were performed: Gram method, catalase, coagulase, thermonuclease, DNAse activity and oxidation and fermentation $(\mathrm{O} / \mathrm{F})$ of glucose and mannitol.

In the detection of E. coli, the Fluorocult LMX "Broth Modifiel acc. to Marrafi and Osmer, was used, in accordance with Merck (2000). In the tubes with indication of E.coli the Kovac's reagent was added. The positive tubes were streaked with Eosin Methylene Blue (EMB) Agar (Merck). The API20E kit (BioMérieux) was used to complement the biochemical tests and the final identification was performed using the API LAB Plus software (BioMérieux). For the enumeration of Enterococcus spp., according to Merck (2000), the tubes with Chromocult broth (Merck) were inoculated and incubated for 48 hours at $45^{\circ} \mathrm{C}$. Tubes positive for Enterococcus (bluish color) were streaked with Chromocult Agar (Merck) and incubated at $35^{\circ} \mathrm{C}$ for $48 \mathrm{~h}$. Typical colonies were tested for differential Gram staining.

Salmonella spp. were detected as described by Pignato et al. (1995). For the identification and isolation, $25 \mathrm{~g}$ of each sample were aseptically 
transferred to $225 \mathrm{~mL}$ of preenrichment broth base "Salmosyst" (Merck), homogenized in stomacher for $4 \mathrm{~min}$ and incubated at $37^{\circ} \mathrm{C} / 6$ hours. For the selective Salmosyst enrichment, $10 \mathrm{~mL}$ of preenrichment broth base was supplemented with one selective supplement tablet (Merck) and incubated for 18 hours at $37^{\circ} \mathrm{C}$. From each tube, a loopful of growth was streaked with Rambach agar (Merck), and the plates were incubated at $37^{\circ} \mathrm{C} / 24$ hours. Typical colonies of Rambach agar were selected and transferred to tubes containing Agar Triple Sugar Iron (TSI) (Himedia) and Lysine Iron Agar (LIA), incubated at $37^{\circ} \mathrm{C} / 24$ hours. Characteristic strains of Salmonella spp. were tested for differential staining of Gram, catalase and oxidase. To complement these biochemical tests was used the API20E kit (BioMérieux) and the final identification was performed using the API LAB Plus software (BioMérieux).

For the antimicrobial susceptibility test, the antimicrobials penicillin G (10UI/disc), teicoplanin $(30 \mu \mathrm{g} / \mathrm{disc})$, vancomycin $(30 \mu \mathrm{g} / \mathrm{disc})$, chloramphenicol $\quad(30 \mu \mathrm{g} / \mathrm{disc}), \quad$ erythromycin $(15 \mu \mathrm{g} / \mathrm{disc})$, gentamycin $(10 \mu \mathrm{g} / \mathrm{disc})$, clindamycin $(2 \mu \mathrm{g} / \mathrm{disc})$, tetracycline $(30 \mu \mathrm{g} / \mathrm{disc})$, aztreonam $(30 \mu \mathrm{g} / \mathrm{disc})$, ceftriaxone $(30 \mu \mathrm{g} / \mathrm{disc})$, cefoxitin $(30 \mu \mathrm{g} / \mathrm{disc})$ and oxacillin $(1 \mu \mathrm{g} / \mathrm{disc})$ were used following the recommendations of the Clinical and Laboratory Standards Institute (CLSI, 2011). Staphylococcus strains were grown on Caso Agar (Merck) for 24 hours at $37^{\circ} \mathrm{C}$. The strains were inoculated in $4 \mathrm{~mL}$ of sterile distilled water to achieve the $\mathrm{n}^{\circ} 0.5$ McFarland turbidity standard (Probac, Brazil). A swab was used to spread the inoculum across the surface of Muller Hinton agar (Merck), and then antibiotic disks (DME Polisensidisc ® 4x6-Specialized Diagnostic Microbiology, São Paulo, Brazil) were applied to the plate. Strain resistance was assessed by measuring the zone of inhibition of bacterial growth after incubation for $24 \mathrm{~h}$ at $37^{\circ} \mathrm{C}$. Staphylococcus aureus ATCC 25923 was used for quality control testing.

In the statistical analysis, Chi-Square test was performed to test the frequency and average of each isolated microorganism in the samples and the Student $\mathrm{T}$ test to compare the differences between population averages of the microorganisms present in the bile and gallbladder epithelium. Fisher's exact test was performed to test the correlation between the frequencies of antimicrobial resistance in the bile and gallbladder epithelium by Staphylococcus strains. A $P$ value below 0.05 was considered significant. The software used for statistical analysis was Biostat 2.0.

\section{RESULTS AND DISCUSSION}

The microorganisms researched in this study were: Salmonella spp., AMHB, Escherichia coli, Enterococcus spp., Enterobacteriaceae family and Staphylococcus spp. Species of the Enterococcus genus were not isolated in the gallbladder samples. There was a higher percentage of isolates for Salmonella spp. and E.coli (Table 1).

The frequency of isolation of the microorganisms in the epithelium of the gallbladder was of $64.03 \%$, and in the bile it was $35.97 \%$ (Table 1). For Salmonella, E. coli and Staphylococcus spp. no significant statistic difference was verified, so the frequency of these microorganisms in the gallbladder was the same, demonstrating they are in the bile or in the epithelium, a common environment for the microorganisms isolated. According to Hancke et al. (1986), the isolation of bacteria in the bile normally coincides with the presence of bacteria in the epithelium, but the ones in the epithelium are more frequently isolated. According to Prouty and Gunn (2003) this occurs because the bacteria reside in the gallbladder, the storage site for bile.

The frequency of isolation of Salmonella spp. was 24.46, with a little more than half found in the epithelium. Salmonella resides in the gallbladder of cattle and goats and contributes to the persistent carrier status of these animals (Woldemariama et al., 2005). Previous studies report the presence of Salmonella in gallbladders of ruminants (McDonough et al., 2000; Chandra et al., 2006; Akoachere et al., 2009). According to Van Velkinburgh and Gunn (1999), Salmonella are highly resistant to the bile, with MBC (Minimal Bactericidal Concentration) between 30 and $60 \%$. Thus, the responses of Salmonellae to bile are important for virulence and also for the establishment of chronic infections or carrier states in the host (Spector and Kenyon, 2011). 
Table 1. Types and frequencies of microorganisms isolated from the bile and gallbladder epithelium of 30 slaughtered cattle

\begin{tabular}{cccccccc} 
Microorganism & \multicolumn{7}{c}{$\mathrm{N}^{\mathbf{0}}$ of isolates Percentage (\%) } \\
\cline { 2 - 8 } & Bile & Epithelium & Total & $\begin{array}{c}P \text { - } \\
\text { value }\end{array}$ & Bile & Epithelium & Total \\
\cline { 2 - 8 } Salmonella spp. & 16 & 18 & 34 & 0.79 & 11.51 & 12.95 & 24.46 \\
AMHB & 8 & 24 & 32 & 0.0001 & 5.75 & 17.27 & 23.02 \\
E. coli & 13 & 21 & 34 & 0.06 & 9.35 & 15.11 & 24.46 \\
Enterobacteriaceae & 5 & 14 & 19 & 0.02 & 3.60 & 10.07 & 13.67 \\
Staphylococcus spp. & 8 & 12 & 20 & 0.41 & 5.76 & 8.63 & 14.39 \\
Total & 50 & 89 & 139 & & 35.97 & 64.03 & 100.00 \\
\hline
\end{tabular}

* Chi-square test.

In the present study, another Gram negative bacteria, isolated with the same frequency as Salmonella spp was E. coli, although great part of it was adhered to the epithelium. The enterobacteria counting presented $13.67 \%$ of isolations in the samples, with a higher count in the epithelium (Table 1). Contrepois et al. (1986); Onyekaba and Njoku (1986); Stoffregen et al. (2004); Reinstein et al. (2006) and Jeong et al. (2007) detected E.coli in the gallbladders of cattle demonstrating that this organism can live permanently in the organ. According to Stoffregen et al. (2004), the gallbladder is a possible niche for $E$. coli in cattle, as it is for other enteric pathogens, notably Salmonella. The gallbladder may be a site of and a source of gastrointestinal Shiga Toxin-producing E. coli (STEC), which can contaminate beef products.

The AMHB frequency was of $23.02 \%$, for the most part isolated from the epithelium (Table 1). The occurrence of AMHB and other prokaryotes found in the gallbladder call our attention to care and need for changes in the current method of liver inspection since, according to the standardization of techniques for cattle slaughtering (Brasil, 1971), in the pos-mortem exam of cattle liver, the gallbladder is compressed, and incised as needed. Because gallstones have considerable market value as research samples, it is common to open the gallbladder at the slaughterhouse. As a result, bile is frequently spilled, often on the liver (Dias et al., 2010). Therefore, evisceration should be done carefully and the bile duct should be tied before removing the gallbladder to prevent crosscontamination with bile.

The frequency of Staphylococcus spp. was $14.39 \%$, considered high in this research, where $8.63 \%$ were present in the epithelium of the gallbladder and the other corresponding $5.76 \%$ in the bile (Table 1). Biochemical tests allowed the identification of coagulase negative Staphylococcus, coagulase positive Staphylococcus and coagulase positive Staphylococcus aureus present in the epithelium and bile. In the bile, the highest percentage of staphylococci found corresponded to coagulase positive Staphylococcus and in the epithelium it was Staphylococcus coagulase negative (Figure 1).

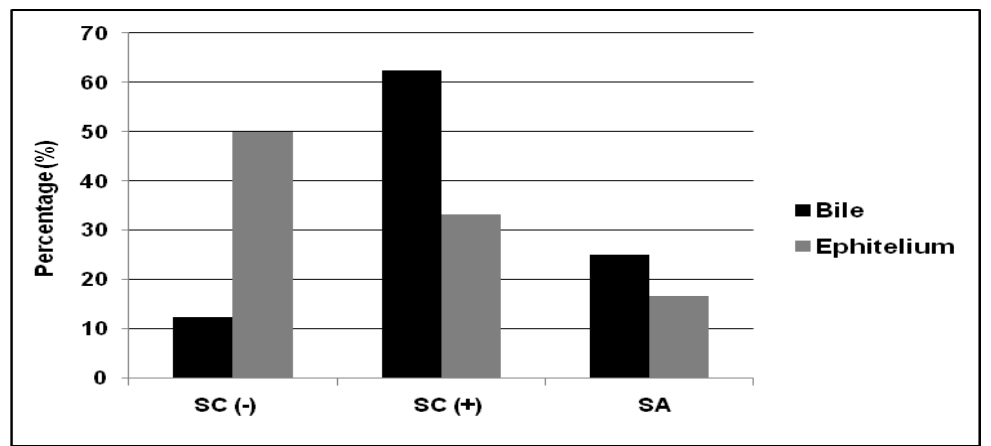

Figure 1. Frequency (\%) of coagulase negative Staphylococcus (SC (-)), coagulase positive Staphylococcus (SC (+) and S. aureus (SA) present in the bile and epithelium of gallbladders from 30 slaughtered cattle. 
Gram positive bacteria seem to be more sensitive to the deleterious effects of bile than Gram negative bacteria and bile salts are often used in their selective enrichment (e.g. Mac Conkey agar, Salmonella-Shigella agar, violet red bile agar and bile esculin agar) (Bridson, 1995). However, Begley et al. (2005 and 2009) demonstrated that the L. monocytogenes strain is able to tolerate concentrations of bovine, porcine and human bile well in excess of those encountered in vivo. Clostridium spp. and Clostridium perfringens were isolated from human and animal bile suggesting an inherent bile tolerance in this pathogen (Sakaguchi et al. 1983; Cable et al., 1997). Ohtomo et al. (1981) demonstrated the capacity of growth of $S$. aureus, through encapsulation, in several concentrations of biliary acids. Liau and Hash (1977) affirmed that the taurine (a compound present in conjugated biliary acids) was detected in the capsular material produced by $S$. aureus strains, being one of the components of the surface Polysaccharide of the Antigen (SPA).

The effect of bile on Gram positive enteric bacteria is not well understood, but some of the mechanisms found in Gram negatives are likely to be found in Gram positive enteric bacteria as well. An observation made by several investigators is that bile tolerance is a strain-specific trait and species tolerances cannot be generalized (Begley et al., 2005). This result allows questioning of the theoretical basis that bile salts are inhibitors of Gram positive bacteria and used as a component in bacteriological media selective for Gram negative microorganisms.

In antimicrobial susceptibility testing, strains of Staphylococcus from both bile and gallbladder epithelium showed sensitivity to the antimicrobials: penicillin G, ceftriaxone, chloramphenicol and gentamicin (Table 2). In the epithelium, strains of Staphylococcus were sensitive also to teicoplanin and vancomycin. The frequency of resistance in the bile and the epithelium was statistically significant to some antimicrobials. Staphylococcal strains present in the epithelium were more susceptible to drugs: erythromycin, teicoplanin, vancomycin and cefoxitin. Because bacteria are aggregated in larger number in the epithelium, there is the occurrence of a low metabolic rate of cells due to low availability of nutrients as reported by Cloete (2003), which fits the gallbladder, and becomes an interfering factor of antimicrobial resistance in the microbial population.

Table 2. Percentage of Staphylococcus strains resistant to antimicrobials isolated from the bile and epithelium of the gallbladders of slaughtered cattle

\begin{tabular}{lccc}
\hline Antimicrobials & Bile $(8$ strains $)$ & Epithelium $(12$ strains $)$ & $P$ - value \\
\hline Clindamycin & 0.00 & 16.66 & 0.49 \\
Erythromycin & 87.50 & 25.00 & 0.01 \\
Oxacillin & 0.00 & 8.30 & 1.00 \\
Penicillin G & 0.00 & 0.00 & $----*$ \\
Teicoplanin & 37.50 & 0.00 & 0.04 \\
Vancomycin & 50.00 & 0.00 & 0.01 \\
Aztreonam & 87.50 & 91.66 & 1.00 \\
Cefoxitin & 87.50 & 33.33 & 0.02 \\
Ceftriaxone & 0.00 & 0.00 & $---*^{\mathrm{a}}$ \\
Chloramphenicol & 0.00 & 0.00 & $---{ }^{*}$ \\
Gentamicin & 0.00 & 0.00 & $---*^{*}$ \\
Tetracycline & 75.00 & 50.00 & 0.37 \\
\hline
\end{tabular}

${ }^{\mathrm{a}}$ Fisher's exact test

* Value not calculated. Susceptible strains in both environments.

In this survey, one strain present in bile and two strains isolated in the gallbladder epithelium were resistant to seven and five antimicrobials tested, respectively. The ability of Staphylococcus spp. to survive the harsh environment of the gallbladder and become resistant to antimicrobials highlights the need for special care to be taken during the raising and slaughter of cattle in order to prevent contamination. 
Regarding the bacterial numbers, there were variations between the value found for the epithelium and the bile (Table 3), prevailing the highest average for the epithelium in the gallbladder. By the Student T test, it was possible to find a significant difference between $\mathrm{CFU} / \mathrm{g}$ and $\mathrm{CFU} / \mathrm{mL}$ population averages in microorganisms present in both gallbladder environments.

Table 3. Counting average of microorganisms present in bile and epithelium of the cattle gallbladders*

\begin{tabular}{lcc} 
Microorganisms & $\begin{array}{c}\text { Average counting in bile } \\
(\mathrm{CFU} / \mathrm{mL})\end{array}$ & $\begin{array}{c}\text { Average counting in the } \\
\text { epithelium }(\mathrm{CFU} / \mathrm{g})\end{array}$ \\
\hline AMHB & $1.8 \times 10^{3 \mathrm{a}}$ & $2.9 \times 10^{6 \mathrm{~b}}$ \\
E. coli & $1.2 \times 10^{3 \mathrm{a}}$ & $2.4 \times 10^{5 \mathrm{~b}}$ \\
Enterobacteriaceae & $4.7 \times 10^{3 \mathrm{a}}$ & $1.3 \times 10^{6 \mathrm{~b}}$ \\
Staphylococcus spp. & $5.2 \times 10^{3 \mathrm{a}}$ & $5.8 \times 10^{5 \mathrm{~b}}$ \\
\hline
\end{tabular}

*For each row, mean values with different letters are significant $(P<0.05)$ according to the Student $\mathrm{T}$ test.

Considering the results obtained in this study, it can be affirmed that the environment for the microorganism in the gallbladder is common. The bacteria can be isolated in the bile as well as in the epithelium, but in larger quantities in the epithelium. Assumptions can be made regarding the frequency and average counting of microorganisms, such as, for example, the permanence of the microorganism in the gallbladder due to its adherence to the epithelium, being its habitat, although due to the organ's contractility, there is a detachment of the bacteria in the epithelium and migration toward the bile. According to Begley et al. (2009) and Steenackers et al. (2011) intestinal pathogens are also able to adhere to and subsequently form bacterial communities, microcolonies and even mature biofilms on epithelial cells.

\section{CONCLUSION}

The gallbladder supports a high number of microorganisms such as Salmonella, E. coli and Staphyloccocus. The ability of Salmonella and Staphyloccocus to survive the harsh environment of the gallbladder and become resistant to antimicrobials highlights the need for special care to be taken during the raising and slaughter of cattle in order to prevent contamination. Moreover, the gallbladder of cattle should be recognized as a reservoir of some pathogens that are multidrug resistant and of great importance to public health.

\section{ACKNOWLEDGMENT}

The authors wish to acknowledge $\mathrm{CNPq}$ (Conselho Nacional de Desenvolvimento Científico e Tecnológico) for scholarship and financial support.

\section{REFERENCES}

AKOACHERE, J.F.T.K.; TANIH, N.F.; NDIP, L.M.; NDIP, R.N. Phenotypic characterization of Salmonella Typhimurium isolates from food-animals and abattoir drains in Buea, Cameroon. J. Health Popul. Nut., v.27, p.612-618, 2009.

BEGLEY, M.; GAHAN, C.G.M.; HILL, C. The interaction between bacteria and bile. Microbiol. Rev., v. 29 , p.625-651, 2005.

BEGLEY, M.; KERR, C.; HILL, C. Exposure to bile influences biofilm formation by Listeria monocytogenes. Gut Pathog., v.1, p.1-4, 2009.

BRASIL, Ministério da Agricultura, Pecuária e Abastecimento. Instrução Normativa $n^{\circ} 62$, de 26 de agosto de 2003. Oficializa os Métodos Analíticos Oficiais para controle de Produtos de Origem Animal e Água. Diário Oficial da República Federativa do Brasil, Brasília, DF, p.6, 5 abr. 2003. Seção 1.

BRASIL, Ministério da Agricultura, Pecuária e Abastecimento. Inspeção de carnes; padronização de técnicas, instalações e equipamentos. Brasília, DIPOA/DICAR, 1971.

BRIDSON, E.Y. (Ed.). The Oxoid Manual. 6th ed.. Unipath Ltd, Basingstoke: Wade Road. Basingstoke, England, 1995.

CABLE, C.S.; REHBUN, W.C.; FORTIER, L.A. Cholelithiasis and cholecystitis in a dairy cow. J. Am. Vet. Med. Assoc., v.211, p.899-900, 1997.

CHANDRA, M.; SINGH, B.R.; SHANKAR, H. et al. Study on prevalence of Salmonella infection in goats. Small Rumin. Res., v.65, p.24-34, 2006.

CLOETE, T.E. Resistance mechanisms of bacteria to antimicrobial compounds. Int. Biodet. Biodeg., v.51, p.277-282, 2003. 
CLSI. Clinical and Laboratory Standards Institute. Performance standards for antimicrobial susceptibility testing; twenty first informational supplement. CLSI document M100-S21. Wayne, Pa.: CLSI. 23 pp. 2011.

CONTREPOIS, M.; DUBOURGUIER, H.C.; PARODI, A.L. et al. Septicaemic Escherichia coli and experimental infection of calves. Vet. Microbiol., v.12, p.109-118, 1986.

DIAS, F.S.; SANTOS, I.F.; FRANCO, R.M.; NASCIMENTO, E.R. Antimicrobial resistance in Salmonella spp. isolated from cattle gallbladder slaughtered in the south of the state of Rio de Janeiro. Rev. Bras. Cienc. Vet., v.17, p.104-107, 2010.

GUNN, J.S. Mechanisms of bacterial resistance and response to bile. Microbes Infect., v.2, p.907-913, 2000.

HANCKE, E.; NUSCHE, A.; MARKLEIN, G. Bacteria in the gallbladder wall and in gallstones. Langenb. Arch. Chir., v.368, p.249-254, 1986.

JENSEN, P.O.; GIVSKOV, M.; BJARNSHOLT, T.; MOSER, C. The immune system vs. Pseudomonas aeruginosa biofilms. FEMS Immunol. Med. Microbiol., v.59, p.292-305, 2010.

JEONG, K.C.; KANG, M.Y.; HEINKE, C. et al. Isolation of Escherichia coli O157:H7 from the gallbladder of inoculated and naturally-infected cattle. Vet. Microbiol., v.119, p.33345, 2007.

LIAU, D.F.; HASH, J.H. Structural analysis of the surface polysaccharide of Staphylococcus aureus. J. Bacteriol., v.131, p.194-200, 1977.

MCDONOUGH, P.L.; SHIN, S.J.; LEIN, D.H. Diagnostic and public health dilemma of lactosefermenting Salmonella enterica serotype Typhimurium in cattle in the Northeastern United States. J. Clin. Microbiol., v.38, p.1221-1226, 2000.

MERCK. Microbiology Manual. Germany: Laboratory Products Division, Merck, Darmstadt, 2000. 407p.

ONYEKABA, C.O.; NJOKU, H.O. Bacteria and helminth isolates from bile and faeces of zebu cattle slaughtered for human consumption in the Niger Delta areas of Nigeria. Ann. Trop. Med. Parasitol., v.80, p.421-424, 1986.
OHTOMO, T.; YOSHIDA, K.; SAN CLEMENTE, C.L. Effect of bile acid derivatives on taurine biosynthesis and extracellular slime production in encapsulated Staphylococcus aureus S-7. Infect. Immun., v.31, p.798-807, 1981.

PIGNATO, S.; MARINO, A.M.; EMANUELE, M.C. et al. Evaluation of New Culture Media for Rapid Detection and Isolation of Salmonellae in Foods. Appl. Environ. Microbiol., v.61, p.1996-1999, 1995.

PROUTY, A.M.; GUNN, J.S. Comparative analysis of Salmonella enterica serovar Typhimurium biofilm formation on gallstones and on glass. Infect. Immun., v.71, p.7154-7158, 2003.

REINSTEIN, S.; FOX, J.T.; SHI, X.; NAGARAJA, T.G. Prevalence of Escherichia coli $\mathrm{O} 157: \mathrm{H} 7$ in Gallbladders of Beef Cattle. Appl. Environ. Microbiol., v.73, p.1002-1004, 2007.

SAKAGUCHI, Y.; MURATA, K.; KIMURA, M. Clostridium perfringens and other anaerobes isolated from bile. J. Clin. Pathol., v.36, p.345-349, 1983.

SPECTOR, M.P.; KENYON, W.J. Resistance and survival strategies of Salmonella enterica to environmental stresses. Food Res. Int., v.45, p.455481, 2011

STEENACKERS, H.; HERMANS, K.; VANDERLEYDEN, J.; DE KEERSMAECKER, S.C.J. Salmonella biofilms: An overview on occurrence, structure, regulation and eradication. Food Res. Int., v.45, p.502-531, 2011.

STOFFREGEN, W.C.; POHLENZ, J.F.L.; NYSTROM, E.A.D. Escherichia coli O157:H7 in the gallbladders of experimentally infected calves. J. Vet. Diagn. Invest., v.16, p.79-83, 2004.

VAN VELKINBURGH, J.C.; GUNN, J.S. PhoPpho $Q$ regulated loci are required for enhanced bile resistance in Salmonella spp. Infect. Immun., v.67, p.1614-1622, 1999.

WOLDEMARIAMA, E.; MOLLA, B.; ALEMAYEHU, D.; MUCKL, A. Prevalence and distribution of Salmonella in apparently healthy slaughtered sheep and goats in Debre Zeit, Ethiopia. Small Rumin. Res., v.58, p.19-24, 2005. 